\title{
Erratum to: In Vitro Considerations to Support Bioequivalence of Locally Acting Drugs in Dry Powder Inhalers for Lung Diseases
}

\author{
S. L. Lee, ${ }^{1,2}$ W. P. Adams, ${ }^{1}$ B. V. Li, ${ }^{1}$ D. P. Conner, ${ }^{1}$ B. A. Chowdhury, ${ }^{1}$ and L. X. Yu ${ }^{1}$
}

Published online 10 November 2010

A typographical error was made in Equation 2.

The specific resistance was expressed as:

$$
\mathrm{R}=\mathrm{Q} / \Delta \mathrm{P}^{2}
$$

The specific resistance should be expressed as:

$$
\mathrm{R}=\Delta \mathrm{P}^{0.5} / \mathrm{Q}
$$

The online version of the original article can be found at http://dx.doi. org/10.1208/s12248-009-9121-4.

\footnotetext{
${ }^{1}$ Office of Generic Drugs, Center for Drug Evaluation and Research, US Food and Drug Administration, Rockville, MD 20855, USA

${ }^{2}$ To whom correspondence should be addressed. (e-mail: sau.lee@ fda.hhs.gov)
} 